JURNAL PLANS

Penelitian Ilmu Manajemen \& Bisnis

ISSN: 1978-7057

\title{
PENGARUH KEPEMIMPINAN DAN MOTIVASI TERHADAP KINERJA KARYAWAN PADA PT. RAJAWALI NUSINDO CAB. MEDAN
}

\author{
Resnita Mersalina Simbolon \\ Alumni Jurusan Manajemen Fakultas Ekonomi Universitas Negeri Medan \\ Nurul Wardani Lubis \\ Dosen Jurusan Manajemen Fakultas Ekonomi Universitas Negeri Medan
}

\begin{abstract}
Human resources or employee is the main driver of the success of a company that needs special attention from the company so that employees can work more diligently in order to achieve company goals. The purpose of this study was to determine the effect of leadership and motivation on employee performance at PT. Rajawali Nusindo Medan Branch. The study population was all employees at PT. Rajawali Nusindo Medan Branch karyawanya number reached 73 (seventy-three). The samples used total sampling so that the sample drawn from the entire population. The data used in this study are primary data obtained through questionnaires in the study sample, amounting to 73 respondents. The test used is the quality of the test data and test the classical assumptions. Hypothesis testing is done by multiple regression analysis, simultaneous $F$ test and the partial test. The result showed that simultaneous leadership and motivational variables affect the performance of employees at PT. Rajawali Nusindo Medan Branch, where the F count $>F$ table or $16.196>3.128$ with a level of significant $(\alpha) 0,000<$ 0,005 . The coefficient of determination (adjusted $R$ square) of 0.316 means that the influence of leadership and motivation on the performance of employees of PT. Rajawali Nusindo Medan Branch $31.6 \%$ and the remaining $68.4 \%$ is influenced by other variables outside of research. Conclusions from the research that there is a positive and significant effect of leadership and motivation on employee performance at PT. Rajawali Nusindo Medan Branch. It is expected that the people at the at PT. Rajawali Nusindo Medan Branch further enhance the leadership and motivation so that employees work even harder to compete and will automatically improve its performance in the company.
\end{abstract}

Keywords: Leadership, Motivation, Performance

\section{PENDAHULUAN}

Sumber daya manusia atau karyawan adalah motor penggerak utama suksesnya sebuah perusahaan. Walaupun perusahaan menyediakan sarana dan prasarana yang memadai tetapi tidak didukung oleh kemampuan dari karyawannya, kegiatan perusahaan tidak akan berjalan dengan baik. Karyawan yang memiliki keterampilan dan berpengetahuan akan bekerja secara maksimal sehingga kinerja karyawan meningkat. Menurut Wirawan (2005) dalam Potu(2013), 'kinerja adalah keluaran yang dihasilkan oleh fungsifungsi atau indikator-indikator suatu pekerjaan atau suatu profesi dalam waktu tertentu.' Upaya peningkatan kinerja karyawan merupakan tantangan yang besar bagi manajemen perusahaan karena kesuksesan dan kelangsungan hidup perusahaan bergantung pada tingkat kinerja karyawannya. 
ISSN: 1978-7057

Disamping itu persaingan global dalam dunia usaha sudah semakinterlihat. Perusahaan dituntut untuk mampu menghadapi perkembangan jaman dan kemajuan teknologi dalam dunia usaha. Untuk itu perusahaan perlu melakukan perubahan-perubahan yang berkesinambungan sesuai dengan perkembangan teknologi yang terjadi.Perusahaan juga sangat mengharapkan kinerja karyawan yang tinggi. Karyawan dituntut untuk selalu bekerja secara efektif dan efisien.Salah satu strategi yang bisa dilakukan perusahaan adalah melaluipemanfaatan sumber daya manusia secara efisien dan efektif serta peningkatan kualitas sumber daya manusia. Hal ini dapat berdampak kepada peningkatan produktifitas perusahaan. Peningkatan produktifitas ini disebabkan oleh kinerja karyawan yang baik. Dengan begitu perusahaan dapat terus berkembang dan mampu bertahan dalam persaingan global Menurut Reza (2010) terdapat beberapa faktor yang dapat menyebabkan kinerja karyawan menjadi rendah diantaranya; kurangnya keinginan karyawan untuk mencapai suatu prestasi di perusahaan, kurangnya ketepatan waktu dalam penyelesaian pekerjaan sehingga kurang menaati peraturan, adanya pengaruh dari lingkungan seperti rekan-rekan kerja yang tidak lagi bersemangat dalam bekerja dan tidak adanya contoh yang harus dijadikan acuan dalam pencapaian prestasi kerja yang baik.

Untuk mencegah hal tersebut tidak terjadi, diperlukan dorongan dan motivasi yang memicu karyawan untuk bekerja sesuai dengan target yang telah ditentukan
perusahaan.Perusahaan membutuhkan seorang pemimpin yang mampu merangkul seluruh karyawan, pemimpin yang mampu mempengaruhi karyawan melalui dorongan-dorongan yang diberikan agar karyawan dapat bekerja secara maksimal. Pemimpin juga harus mampu menyampaikan dan menjelaskan visi misi perusahaan kepada karyawannya secara jelas dengan bahasa yang mudah dimengerti.

Kepemimpinan merupakan salah satu faktor yang paling dominan dalam mempengaruhi kinerja karyawan baik secara individual, kelompok maupun organisasi."Kepemimpinan

didefenisikan sebagai tindakan atau upaya untuk memotivasi atau mempengaruhi orang lain agar mau bekerja atau bertindak ke arah pencapaian tujuan organisasi yang telah ditetapkan" (Iman \& Siswandi, 2007:112).

PT. Rajawali Nusindo Cab. Medan adalah perusahaan yang bergerak di bidang penyediaan produk farmasi dan alat kesehatan, produk pertanian, produk umum dan jasa distribusi dan perdagangan. Sebagai perusahaan yang bergerak dibidang jasa, PT. Rajawali Nusindo Cab. Medan sangat menyadari pentingnya kinerja karyawan sebagai salah satu faktor yang menentukan apakah perusahaan bisa mencapai tujuannya. Karena karyawan yang lebih sering berinteraksi secara langsung dengan pelanggan, karyawan harus bisa memberikan pelayanan yang baik kepada pelanggan. Jika karyawan sudah bisa memberikan pelayanan yang baik, berarti kinerja karyawan juga baik. 
ISSN: 1978-7057

Pelayanan yang baik ini akan menumbuhkan kepercayaan dan rasa puas pelanggan terhadap perusahaan dan akhirnya pendapatan perusahaan akan meningkat.

Motivasi dari dalam diri karyawan di PT.Rajawali Nusindo Cab.Medan sangat kurang. Dilihat dari lokasi kerja karyawan yang sebagian besar berada di lapangan (luar kantor), sudah pasti karyawan merasa lelah setelah melakukan pekerjaannya. Hal ini menyebabkan karyawan malas untuk melanjutkan pekerjaannya. Selain itu terjadinya pergantian pemimpin perusahaan yang menyurutkan semangat kerja karyawan karena sebagian karyawan merasa tidak cocok dengan atasan yang baru.

\section{METODE PENELITIAN \\ Lokasi dan Waktu Penelitian}

Lokasi dari penelitian ini adalah di PT. Rajawali Nusindo Cab. Medan Jln. Gatot Subroto Km. 5 No. 146, Medan, Indonesia 20113. Penelitian ini dilaksanakan pada bulan Agustus sampai dengan selesai.

\section{Populasi dan Sampel}

Jumlah populasi dari penelitian ini adalah seluruh karyawan PT. Rajawali Nusindo Cabang Medan yang berjumlah 73 orang. Berikut adalah jumlah karyawan pada setiap bagian pada PT. Rajawali Nusindo Cab. Medan. Menurut Sugiyono (2012:116), sampel adalah bagian dari jumlah dan karakteristik yang dimiliki oleh populasi tersebut. Menurut Arikunto (http://widisudharta.weebly.com/meto de-penelitian-skripsi.html), penentuan pengambilan sample adalah apabila kurang dari 100 lebih baik diambil semua hingga penelitiannya merupakan penelitian populasi. Berdasarkan pendapat diatas maka penulis menggunakan metode Total Sampling dengan mengambil sampel yaitu seluruh karyawan yang ada di PT. Rajawali Nusindo Cabang Medan.

\section{Analisis Regresi Berganda}

Analisa regresi berganda adalah analisis yang bertujuan untuk mengetahui pengaruh antara variabel bebas (kepemimpinan dan motivasi) dan variabel terikat (kinerja karyawan). Persamaan regresi berganda dituliskan dengan rumus sebagai berikut:

$$
\begin{array}{cl}
\mathbf{Y}=\mathbf{a}+\mathbf{b}_{\mathbf{1}} \mathbf{X}_{\mathbf{1}}+\mathbf{b}_{\mathbf{2}} \mathbf{X}_{\mathbf{2}}+\mathbf{e} \\
\text { Keterangan : } \\
\mathrm{Y} \quad \begin{array}{l}
=\text { kinerja karyawan, sebagai } \\
\text { variabel terikat }
\end{array} \\
X_{1} \quad \begin{array}{l}
= \\
\text { variabel bebas }
\end{array} \\
X_{2} \quad \begin{array}{l}
=\text { motivasi,sebagai variabel } \\
\text { bebas }
\end{array} \\
\text { a } \quad \text { konstanta } \\
\text { b1,b2 } & =\text { koefisien regresi berganda } \\
& \text { yang dicari }
\end{array}
$$

\section{Uji Simultan}

Uji simultan dimaksudkan untuk mengetahui apakah semua variabel bebas mempunyai pengaruh yang sama terhadap variabel terikat. Pengujian yang dilakukan menggunakan uji F. Jika $\mathrm{F}>$ Ftabel maka menolak hipotesis nol (Ho) dan menerima hipotesis alternatif (Ha), artinya semua variabel bebas secara bersama-sama berpengaruh terhadap variabel terikat (Algifari, 2000:71)

\section{Uji Parsial}

Uji parsial atau koefisien regresi dimaksudkan untuk memastikan apakah variabel bebas yang terdapat dalam persamaan tersebut secara individu berpengaruh secara signifikan terhadap nilai 
JURNAL PLANS

Penelitian Ilmu Manajemen \& Bisnis

ISSN: 1978-7057

variabel terikat. Caranya dengan melakukan pengujian terhadap koefisien regresi setiap variabel bebas dengan menggunakan uji t.

\section{Analisis Determinasi}

Analisis determinasi $\left(R^{2}\right)$ digunakan untuk mengukur besarnya kontribusi persentase sumbangan variabel bebas yang diteliti $\left(\mathrm{X}_{1}, \mathrm{X}_{2}\right)$ terhadap variabel terikat secara bersama-sama dimana $0 \leq R^{2} \leq 1$. Pengujianinidilakukandenganmenggu nakanrumus:

$$
R^{2}=\frac{b\left(n \sum X_{1,2} Y\right)-\left(\sum X_{1,2}\right)\left(\sum Y\right.}{n\left(\Sigma Y^{2}\right)-(\Sigma Y)^{2}}
$$

Dalam penelitian ini dipergunakan alat bantu SPSS (Statistical Packages For the Science) versi 19.00 .

\section{HASIL PENELITIN DAN \\ PEBAHASAN}

\section{Analisis Regresi Berganda}

Model regresi ganda dengan 1 Variabel dependen (Y) yaitu variabel semangat kerja karyawan dan 2 variabel independen (X) yaitu variabel Kepemimpinan $\left(\mathrm{X}_{1}\right)$, dan Motivasi $\left(\mathrm{X}_{2}\right)$ adalah sebagai berikut $\mathbf{Y}=\mathbf{a}+\mathbf{b}_{1} \mathbf{X}_{\mathbf{1}}+\mathbf{b}_{\mathbf{2}} \mathbf{X}_{\mathbf{2}}+\mathbf{e}$

Untukmenguji hipotesis yang menyatakan terdapat pengaruh kepemimpinan $\left(\mathrm{X}_{1}\right), \quad \operatorname{motivasi}\left(\mathrm{X}_{2}\right)$ terhadap kinerja karyawan (Y) digunakan analisis regresi ganda.

Berdasarkan hasil perhitungan diperoleh hasil persamaan regresi ganda adalah sebagai berikut :
Tabel 1. Hasil Perhitungan Regresi Linear Berganda

\begin{tabular}{|l|r|r|r|r|r|}
\hline Model & \multicolumn{2}{|c|}{$\begin{array}{c}\text { Unstandard } \\
\text { ized } \\
\text { Coefficient } \\
\text { s }\end{array}$} & $\begin{array}{c}\text { Standard } \\
\text { ized } \\
\text { Coefficie } \\
\text { nts }\end{array}$ & t & $\begin{array}{r}\text { Si } \\
\text { g. }\end{array}$ \\
\cline { 2 - 4 } & B & $\begin{array}{c}\text { Std. } \\
\text { Erro } \\
\text { r }\end{array}$ & Beta & & \\
\cline { 1 - 3 } (Const & 14,1 & 3,59 & & 3,9 &, 0 \\
ant) & 89 & 8 & & 44 & 00 \\
1 X1 &, 236 &, 233 &, 201 & 2,0 &, 0 \\
& & & & 25 & 09 \\
X2 &, 738 &, 133 &, 549 & 5,5 &, 0 \\
\end{tabular}

a. Dependent Variable: $Y$

Dari data hasil SPSS di atas dapat dijelaskan sebagai berikut : $\mathrm{Y}=\mathbf{1 4 , 1 8 9}+\mathbf{0 , 2 3 6} \mathrm{X}_{\mathbf{1}}+\mathbf{0 , 7 3 8} \mathrm{X}_{\mathbf{2}}+\mathrm{e}$

- Konstan sebesar14,189 menyakan bahwa jika tidak ada variabel $\mathrm{X}$, maka semangat kerja adalah sebesar 14,189 (asumsi faktor lain konstan)

- Koefisien regresi variabel $X_{1}$ sebesar $\quad 0,236$ menyatakan bahwasetiap terjadi perubahan kepemimpinan akan mempengaruhi kinerja sebesar 0,236(asumsi faktor lain konstan)

- Koefisien regresi variabel $X_{2}$ sebesar 0,738menyatakan bahwa setiap terjadi peningkatan motivasi yang baik akan mempengaruhi kinerja sebesar 0,738(asumsi faktor lain konstan)

\section{Pengujian Hipotesis Uji Simultan (Uji F)}

Berdasarkan hasil pengujian statistik (Uji ANOVA/Uji F) dapat dilihat pada tabel hasil berikut : 
ISSN: 1978-7057

Tabel 2. Hasil Uji Perhitungan Uji F ANOVA $^{\mathrm{a}}$

\begin{tabular}{|l|r|r|r|r|c|}
\hline Model & $\begin{array}{c}\text { Sum } \\
\text { of } \\
\text { Squar } \\
\text { es }\end{array}$ & $\begin{array}{c}\mathrm{d} \\
\mathrm{f}\end{array}$ & $\begin{array}{c}\text { Mea } \\
\mathrm{n} \\
\text { Squa } \\
\text { re }\end{array}$ & $\mathrm{F}$ & $\begin{array}{c}\text { Sig } \\
\cdot\end{array}$ \\
\hline Regres & $\begin{array}{r}394,3 \\
\text { sion }\end{array}$ & 2 & 197, & 16,1 &, 00 \\
168 & 96 & $0^{\mathrm{b}}$ \\
1 Residu & 852,1 & 7 & 12,1 & & \\
al & 97 & 0 & 74 & & \\
Total & $\begin{array}{r}1246, \\
533\end{array}$ & 2 & & & \\
\hline
\end{tabular}

a. Dependent Variable: $Y$

b. Predictors: (Constant), X2, X1

Dari hasil pengujian terhadap uji Anova atau F test seperti yang ditampilkan diatas diperoleh nilai $\mathrm{F}$ hitung sebesar 16,196 pada taraf $\alpha=$ 0,05. Adapun $F_{\text {tabel }}$ diperoleh dengan $F_{(1-\alpha)(2,70)}$ adalah 3,128. Dengan demikian Fhitung $>\mathrm{F}$ tabel atau $16,196>3,128$ dengan level of significant $(\alpha) 0,000<0,005$ yang berarti bahwa variable pemberian insentif dan promosi jabatan secara bersama-sama (simultan) berpengaruh terhadap kinerja karyawan pada PT. Rajawali Nusindo Cabang Medan.

\section{Uji Parsial (Uji t)}

Metode dalam penentuan $t$ tabel menggunakan ketentuan tingkat signifikan 5\%, dengan $\mathrm{df}=\mathrm{n}-\mathrm{k}-1$ (pada penelitian ini $(\mathrm{df}=73-2-1=70)$, sehingga didapat nilai $t$ tabel sebesar 1,667. Hasil dari pengujian parsial adalah sebagai berikut:

Tabel 3.Nilai t Hitung

\begin{tabular}{|c|c|}
\hline Variabel & t hitung \\
\hline Kepemimpinan $\left(\mathrm{X}_{1}\right)$ & 2,025 \\
\hline Motivasi $\left(\mathrm{X}_{2}\right)$ & 5,556 \\
\hline \multicolumn{2}{|c|}{ Dari tabel 3. di atas dapat } \\
\hline
\end{tabular}

dijelaskan bahwa :

1. Kepemimpinan berpengaruh positif dan signifikan terhadap Kinerja Karyawan dengan nilai $\mathrm{t}_{\text {hitung }}=2,025>\mathrm{t}_{\text {tabel }}=1,667$ dan probabilitas 0,009 pada tingkat signifikansi 5\%. Hal ini berarti semakin meningkat kepemimpinan, maka kinerja karyawan akan meningkat.

2. Motivasi berpengaruh positif dan signifikan terhadap Kinerja Karyawan dengan nilai $t_{\text {hitung }}=$ $5,556>\mathrm{t}_{\text {tabel }}=1,667$ dan probabilitas 0,000 pada tingkat signifikansi 5\%. Hal ini berarti semakin meningkat motivasi yang diberikan perusahaan, maka semakin meningkat kinerja karyawan.

\section{Uji Determinasi (Uji $\mathbf{R}^{2}$ )}

Determinan digunakan untuk mengetahui seberapa besar variabel independen mampu menjelaskan pengaruh variabel dependen.

Tabel 4. R Square

\begin{tabular}{|r|c|c|c|c|}
\hline $\begin{array}{c}\text { Mode } \\
1\end{array}$ & $\mathrm{R}$ & $\begin{array}{c}\mathrm{R} \\
\text { Squar } \\
\mathrm{e}\end{array}$ & $\begin{array}{c}\text { Adjuste } \\
\mathrm{d} \mathrm{R} \\
\text { Square }\end{array}$ & $\begin{array}{c}\text { Std. } \\
\text { Error of } \\
\text { the } \\
\text { Estimat } \\
\mathrm{e}\end{array}$ \\
\hline 1 & $\begin{array}{r}, 562 \\
\mathrm{a}\end{array}$ &, 316 &, 297 & 3,489 \\
\hline
\end{tabular}

a. Predictors: (Constant), X2, X1

b. Dependent Variable: $Y$

Dari tabel diatas, angka $\mathrm{R}$ sebesar 0,562 menunjukkan bahwa korelasi atau hubungan yang kuat antara variabel independen (kepemimpinan dan motivasi) dengan variabel dependen (kinerja). Koefesien Determinasi ( $\mathrm{R}$ square) t talbedar SigniffokanNilkieputûsán ini

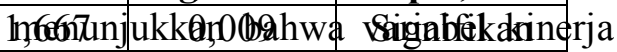
1,6ळ7 dapat 0djojlaskan Södahfikariabel kepemimpinan $\left(\mathrm{X}_{1}\right)$ dan motivasi $\left(\mathrm{X}_{2}\right)$ secara bersama sama sebesar $31,6 \%$ dan sisanya $68,4 \%$ dipengaruhi oleh faktor lain diluar variabel independen.

\section{Pembahasan Hasil Penelitian}

Pada penelitian ini, data yang diperoleh dari penyebaran angket 
yang dilakukan penulis kepada responden (karyawan) di PT. Rajawali Nusindo Cab. Medan kemudian mengumpulkannya kembali. Penelitian ini bertujuan untuk mengetahui pangaruh kepemimpinan dan motivasi terhadap kinerja karyawan. Berdasarkan analisis data penelitian untukvariabel kepemimpinan, hasil t hitung yang diperoleh adalah 2,025 $>1,667$ atau $t$ hitung $>\mathrm{t}$ tabel, dengan signifikan $0,000(\mathrm{p}<0,05)$. Hal ini menunjukkan bahwa variabel kepemimpinan berpengaruh positif dan signifikan secara parsial terhadap varabel kinerja karyawan. Sedangkan untuk variabel motivasi dipeoleh nilai $t$ hitung 5,556 $>1,667$ atau $t$ hitung $>\mathrm{t}$ tabel, dengan signifikan $0,000(p<0,05)$. Hal ini menunjukkan bahwa variebel motivasi juga berpengaruh positif dan signifikan secara parsial terjadap variabel kinerja karyawa.

Berdasarkan hasil pengujian anova (F) diperoleh nilai $\mathrm{F}$ sebesar 16,196. Hal ini menunjukkan bahwa koefisien arah regresi linier berganda (X1 dan X2 terhadap Y) sangat berarti pada taraf signifikan 5\%. Dan berdasarkan hasil pengujian regresi, diperoleh nilai $\mathrm{R}^{2}$ sebesar 0,316 . Hal ini menunjukkan bahwa variabel kepemimpinan (X1) dan variebl motivasi (X2) memiliki pengaruh yang positif dan signifikan secara bersama-sama terhadap variabel kinerja karyawan $(\mathrm{Y})$ sebesar 31,6\% $\left(\mathrm{R}^{2} \mathrm{x} \quad 100 \%\right)$. Sedangkan sisanya $68,4 \%$ dipengaruhi oleh variabel lain diluar model penelitian ini.

Dari hasil ini dapat dikatakan bahwa variabel yang memiliki pengaruh paling besar terhadap variabel kinerja adalah variabel motivasi yaitu sebesar $55,5 \% \quad(\mathrm{t}$ hitung $\mathrm{x} 100 \%$ ) jika dibandingkan dengan variabel kepemimpinan yang pengaruhnya sebesar $20,2 \%$ (t hitung $\mathrm{x} 100 \%$ ). Hal ini disebabkan oleh kurang aktifnya peran pemimpin diperusahaan tersebut. Namun hal tersebut tidak mengurangi motivasi karyawan untuk bekerja dan memberikan yang terbaik bagi perusahaan.

\section{PENUTUP}

Berdasarkan hasil dan pembahasan penelitian, maka penulis membuat beberapa kesimpulan:

1. Variabel kepemimpinan memiliki pengaruh yang positif dan signifikan terhadap kinerja karyawan pada PT. Rajawali Nusindo Cabang Medan. Hal ini dapat dilihat dari hasil uji parsial (uji t) bahwa $t$ hitung yang diperoleh $(2,025)$ lebih besar dari pada $t$ tabel $(1,667)$. Begitu juga dengan variabel motivasi memiliki pengaruh positif dan signifikan terhadap kinerja karyawan pada PT. Rajawali Nusindo Cabang Medan. Hal ini dapat dilihat dari hasil uji parsial (uji t) bahwa $t$ hitung yang diperoleh $(5,556)$ lebih besar dari pada $t$ tabl $(1,667)$.

2. Secara simultan variabel kepemimpinan dan motivasi memiliki pengaruh yang positif dan signifikan terhadap kinerja karyawan pada PT. Rajawali Nusindo Cabang Medan. Dapat dilihat dari hasil uji simultan (uji F) diperoleh sebesar 16,196 > 3,128 (F tabel).

3. Kepemimpinan dan motivasi memiliki pengaruh sebesar 31,6 $\%$ terhadap kinerja karyawan 
pada PT. Rajawali Nusindo Cabang Medan.

\section{DAFTAR PUSTAKA}

Algifari. 2000. Analisis Regresi. Yogyakarta: BPFE

Arifin, Syamsul. 2012. Leadership: Ilmu dan Seni Kepemimpinan. Jakarta: Mitra Wacana Media

Fahmi, Irfan. 2013. Perilaku Organisasi: Teori, Aplikasi dan Kasus. Bandung: Alfabeta

Hadipranoto, Prasetiyo. 2013Tugas Program Pengembangan SDM: Kinerja Pegawai. https://www.academia.edu/54 43600/Kinerja karyawan (Diakses 29 Mei 2014)

Handoko, T. Hani. 2003. Manajemen Edisi 2. Yogyakarta: BPFE

Hasibuan,Malayu. S. P. 2007. Manajemen SDM-Edisi Revisi. Jakarta: BumiAksara.

Iman \& Siswandi. 2007. AplikasiManajemen

Perusahaan:

AnalisisKasusdanPemecahann ya. Jakarta: Penerbit Citra Wacana Media.

Kartono, Kartini. 2005. PemimpindanKepemimpinan. Jakarta: RajaGrafindoPersada , Kartini. 2006.PemimpindanKepemimpi nan. Jakarta: RajaGrafindoPersada

Mangkunegara, Anwar Prabu. 2004. ManajemenSumberDayaManu sia Perusahaan. Bandung: RemajaRosdakarya , Anwar Prabu, 2012. EvaluasiKinerja SDM. Bandung:RefikaAditama

Nugroho, Rakhmat. 2006. Analisis Faktor-faktor yang Mempengaruhi Kinerja
Karyawan Studi Empiris pada PT. Bank Tabungan Negara (Persero) Cabang Bandung. Semarang.UniversitasDiponeg oroeprints.undip.ac.id/18819/ 1/RAKHMAT NUGROHO.pdf (Diakses 14 Januari 2014)

Potu, Aurelia. 2013. Kepemimpinan, Motivasi dan Lingkungan Kerja Pengaruhnya terhadap Kinerja KAryawan pada Kanwil Ditjen Kekayaan Negara Suluttenggo dan Maluku Utara di Manado. Jurnal EMBA, Vol. 1 No. 4, Desember 2013, Hal. 12081218.

http://ejournal.unsrat.ac.id/ind ex.php/emba/article/download 12894/2445 (Diakses 5 Feb 2014)

Rahayu,Vebriana Tri, Vivi Ariyani, dan Soni Kurniawan.2013. Pengaruh Kepemimpinan, Lingkungan Kerja Fisik dan Kompensasi terhadap Kinerja Karyawan di PT. PLN CabangMadiun. Jurnal Riset Manajemen dan Akuntansi Vol. 1 no. 1 Februari 2013.http://portal.widyamanda la.ac.id/jurnal/index.php/jrma/ article/download/87/93(Diakse s 5 Feb 2014)

Reza, Regina Aditya. 2010. Pengaruh Gaya Kepemimpinan, Motivasi dan Disiplin Kerja terhadap Kinerja Karyawan PT. Sinar Santosa Perkasa Banajrnegara.

Semarang.UniversitasDiponeg orohttp://eprints.undip.ac.id/2 4466/1/skripsiREGINA_ADITYA REZA.p df(Diakses 12 Feb 2014) 
JURNAL PLANS

Penelitian Ilmu Manajemen \& Bisnis

ISSN: 1978-7057

Riduwan, 2007. Skala Pengukuran Variabel-Variabel Penelitian. Bandung: Alfabeta

Siagian, Sondang P. 2004. Teori Motivasi dan Aplikasinya. Jakarta: RinekaCipta Sondang P. 2008. Manajemen Sumber Daya Manusia. Bandung: BumiAksara

Sudjana. 2005. MetodaStatistika. Bandung: Tarsito

Sugianto,FranaAgus. 2011. Pengaruh Motivasi Kerjadan Kepemimpinan terhadap Kinerja Karyawan Studi pada PT. Madubaru Yogyakarta. Yogyakarta: Universitas Pembangunan Nasional "Veteran". http://repository.upnyk.ac.id/1 051/1/Frana -

141 040 387.pdf (Diakses

Sugiyono. 2012. MetodePenelitianBisnis. Bandung: Alfabeta

Sutrisno, Edy. 2009. Manajemen Sumber Daya Menusia. Jakarta: Kencana
Terry, George R., dan Leslie W. Rue. 2009.

DasarDasarManajemen. Jakarta: BumiAksara

Wahyudi, Amin, dan Jarot Suryono. 2006. Analisis Pengaruh Gaya Kepemimpinan, Motivasidan Lingkungan Kerja terhadap Kinerja Pegawai. Jurnal Manajemen Sumber Daya Manusia Vol. 1 No. 1 Desember 2006: 1-14. http://ejournal.unisridigilib.ac. id/index.php/Manajemen/articl e/download/67/40 (Diakses 15 Jan 2014)

Wibowo, 2007.ManajemenKinerja. Jakarta: MuraiKencana

Umar, Husein. 2002. Metode Penelitian untuk Skripsi dan Tesis Bisnis. Jakarta: Raja Grafindo Persada

http://id.wikipedia.org/wiki/Kinerja(D iakses 29 Mei 2014)

http://widisudharta.weebly.com/meto de-penelitianskripsi.html(Diakses 5 Juni 2014) 